\section{COMPUTER DESIGN}

\section{Closer Collaboration}

YET another call for university research workers and industrial scientists to exchange views and ideas is made in the Science Research Council's Engineering Board's report on Research Support for Computer Aided Design published recently.

Industry spends more than $£ 1,000$ million on design every year and the Department of Trade and Industry's computer aided design centre has estimated that a twenty per cent saving can be made in a wide range of engineering applications if the engineering industry turns fully to computer aided systems. The actual annual saving would be higher than the calculated $£ 200$ million because a switch to computer design would lead to new concepts and improved manufacturing procedures.

The report pinpoints several areas where industry would benefit from greater use of computer aided design. Traditional skills are dying in the die mould and pattern making industries and several companies are in need of new design and manufacturing techniques. The ship design industry is also a prime contender for the application of computer aided design research and the machining systems industry, according to the report, needs coordination of machine tool design, interactive aids and numerically controlled machine tools so that the industry can move more quickly into manufacturing.

The civil engineering industry is well advanced in the techniques of using computers for designing engineering systems and in integrating design products but the SRC feels that it would be prudent for the industry to now consider integrating design and production, in particular, the report says, so that selection of components, ordering of

\section{Nuffield Trustees}

THE Nuffield Foundation, which last year awarded more than £1 million in grants, will have a new chairman managing of trustees in April. Sir Geoffrey Gibbs, who has been at trustee since the foundation was set up in 1943 and chairman since 1951 , is retiring and will be replaced by Lord Todd, who has been a managing trustee since 1950. Professor Hans Kornberg, who holds the chair of biochemistry at the University of Leicester, was made a trustee of the foundation on January 1 and will fill the breach caused by Sir Geoffrey's retirement. materials and the organization of work on site should be more closely integrated.

But the introduction of these advanced computer ideas into industry needs a flow of information from universities where the basic work is being done. University workers, says the report, "should be made aware that successful contact with industry requires a considerable degree of the researcher's personal time" and it goes on to say that the best means of exchanging ideas is by personal contact, provided it is supported by "adequate and appropriate documentation". Engineers from industry should be encouraged to join university research groups for periods ranging from a week up to a year.

Research in computer aided design would also benefit from a closer knitting of existing groups, especially as the subject calls out for more interdisciplinary cooperation. The research groups should, naturally, have active support from computing science departments and should be active in running post experience courses. But the report does not favour these groups having their own large computers and they should, if the need arises, install terminals connected to a central facility.

The SRC is prepared to support groups setting out to do research in computer-aided design in engineering but the report points out that SRC grants are primarily intended to supplement existing research projects. After a suitable interval the university, or institution, is expected to assume full, or partial, responsibility for the group.

\section{WEATHER RESEARCH}

\section{US/USSR Cooperation}

from our Soviet Correspondent

A JoINT Soviet-United States research expedition to the Bering Sea was inaugurated on January 31,1973 , with the sailing of the Soviet weather ship Priboi from Zolotoi Rog bay, near Vladivostok. In addition to the Priboi, the Soviet team is supplying an Il-18 aircraft equipped as a flying laboratory, while from the American side NASA is providing an icebreaker and an aircraft.

A two-month research programme is planned, which will study the surface of the sea in various temperature conditions, the physical and chemical parameters of sea water, the density and growth of ice and the content of water vapour in the atmosphere. Measurements made from the ships will be compared with data on microwave reflexion from the sea and ice surfaces, recorded by the aircraft.

The programme has been designed under the terms of the 1972 agreement between the Soviet Union and the United States on cooperation in the exploration and use of outer space for peaceful purposes; although no specific mention has been made of satellite data, it would seem that the readings obtained by the Bering expedition will also be compared with those of weather satellites. The material gathered by the expedition is intended for use in the development of weather forecasting methods for Arctic and sub-Arctic waters.

\section{CRIMOND TERMINAL \\ Surveys Continue}

TOTAL OIL MARINE is undertaking further surveys of the east coast of Scotland to examine alternatives to the Crimond site for the gas processing plant needed to handle the output of the Frigg gas field.

The disused airfield at Crimond on which Total and the British Gas Corporation want to build the processing plant lies alongside Loch Strathbeg, which is classified as of grade one scientific importance by the Nature Conservancy (see Nature, 240, 435 ; 1973).

At a meeting in the Buchan village of Crimond last week, Mr David Wood of Total revealed that the coast had only been examined in detail from Fraserburgh to Rattray Head-a distance of a little over eight miles-but added that further surveys are in progress. This week $\mathrm{Mr}$ Wood said that "we are taking a complete look at the whole thing, both offshore and elsewhere". Results, he said, "are expected in weeks rather than months".

The reason for continued surveys, Mr Wood says, is that the Ministry of Defence already has planning permission to use the land for a radio station. If and when the decision on who is to have the land comes to a head "there is no guarantee that energy will get it over defence".

$\mathrm{Mr}$ Wood also concedes that it is likely that only four pipelines could be brought ashore at Crimond. Environmentalists fear that, in spite of the Gas Corporation's policy of concentrating processing plants on as few sites as possible, this might result in a second terminal being built elsewhere if a number of large gas fields are found in the North Sea.

Mr Wood says that he is not surprised by the reaction to the proposal, but he is surprised "that so many people think that they should be consulted first" and that people are "afraid that the local planning authority is likely to produce a fait accompli".

Mr Wood remains confident, however, that the construction of the terminal "will have no effect upon Loch Strathbeg whatsoever". "But getting the pipes to the airfield", he added, "that may be another matter". 